in many plants, and later Terletzki ${ }^{1}$ gave some details. The observations of these authors established the occurrence of protoplasm between the parenchyma cells in a small number of plants, but as I have stated this is not a rare phenomenon, but one of general occurrence, and I have found that the intercellular spaces of the true prosenchymatic tissues may also contain protoplasm.

I have investigated the plasma of the intercellular spaces in various collenchymatic, parenchymatic, and prosenchymatic tissues. For the investigation it is very important to use the reagents (absolute alcohol, picric acid, or osmic acid) very shortly before cutting the sections. Between the larenchyma cells, in the intercellular spaces protoplasm will always be found (bark and medullary parenchyma of the Loranthaceæ, Gingko, \&c.). In longitudinal sections made of thick $\left(2 \frac{1}{2} \mathrm{~cm}\right.$.) branches of Viscum the connection betwcen the medullary parenchyma cells and the protoplasm filling the intercellular spaces is also clearly to be seen. On the contrary. between the thin-walled cells which contain little protoplasm the intercellular plasm cannot, or in very rare instances, be detected (medulla of Phaseolus, Cucurbita, Sambucus, \&c.). In the prosenchymatous tissues, e.g. in the bast-fibre of Viscum-after moderate swelling with sulphuric acidthe intercellular protoplasm, when stained with eosine, is clearly to be observed. The connection of this intercellular protoplasm with the protoplasts of the fibres is easily seen. We find intercellular protoplasm also in the xylem, e.g. in Rhus cotinus.

Most important is a fact which I have discovered in the course of my investigations, namely, the occurrence of inter-lamellar protoplasm. This was present very constantly in the leaves of mistletoe. The sections prepared with dilute sulphuric acid and stained, very exactly showed the fine plasmatic threads, corresponding in their disposition exactly to the middle lamella. This middlelamellary "protoplasm" surrounded the protoplasts as a frame the picture, and ended in the protoplasm of the intcrcellular spaces. The threads are thicker at these points. The greatest precautions must be taken in the investigation of this middle-lamellary plasma: all very strong acids, \&c., should be kept away from the prepared sections. When the cell-wall is very vigorously swelled the fine processes which bind the protoplasts together appear penetrating into the plasma-framc. This plasmaframe surrounds each cell, and in a section the framework of lamellae occur in all planes and in all successive sections, and all the various constituent threads appear to intersect one another at all angles; it is consequently clear that the middle-lamellary plasm forms a plasmatic mantie round the protoplasts which is increased at each edge with the pillar-form (of three to four sides) intercellular plasm portions.

The intercellular plasm prescrves its vitality, and in some instances we observe that some changes take place in the intercellular spaces. The intercellular plasm may be observed to cover itself with a special cell-wall; this membrane is the product of the intercellular plasm. This protoplasm can transform itsclf into a true new cell. In many cases in various tissues we have found this new mode of cell-formation, thus in the collenchymatous tissues (hypoderm of Liriodendron, Ficus, Sambucus, Solanum, Cucurbita, \&c.), or in the xylem (Rhus cotinus), in the common parenchymatous bark (Viscum, Loranthus, \&c.), in the medulla, \&c. These nowly formed colls grow very fast, and are only in their form and appearance different from the older cells. This cell-formation is very rapid, and it appears at first sight that the number of the tisste elements is by these "intercellular cells" (Interstitialceller of J. G. Agardh, ${ }^{2}$ who has observed this metamorphosis in the Floridere, or "between-cells" (Köztisejtek in Hungarian), considerably increased. A consequence of this great and fast growth is the formation

$$
{ }^{1} \text { I. c., p. roig. }
$$$$
2 \text { Botaniska Notiser, r88, p. rзo. }
$$

of new "secondary" or "tertiary" intercellular spaces round the newly formed or transformed cells.

General Results.-I will now briefly conclude with a statement of the general results of my investigations upon the communication of the protoplasts, and upon the intercellular and middle-lamellary plasm.

(I) The protoplasts of all the tissues in united cells are in direct connection by means of finely attenuated protoplasmic threads.

(2) The connective threads traverse the pit-closing membrane (which is of a sieve-plate structure), while in unpitted cells they traverse directly the cell-wall. By these threads is the communication between the connective processes which occupy the pit-cavity from both sides directly established. ${ }^{1}$

(3) The intercellular plasm occurs not only in the intercellular spaces of the parenchymatic tissues, but also in those of true parenchymatic tissues.

(4) This intercellular plasm contains, in many cases, chlorophyll-granules ${ }^{2}$ (Viscum).

(5) The intercellular plasm is in direct connection with the adjacent protoplasts.

(6) Corresponding to the middle lamella around the cells, we find a plasmatic frame; the sides of this frame end in the "intercellular" plasma. This plasmatic frame forms a veritable mantle round the protoplasts, and is increased at each edge by an intercellular plasm portion, which latter has a pillar form.

(7) Tha connective threads of the protoplasts traverse this " middle-lamcllary" plasma ; both are also connected.

(8) The probable origin of the intercellular plasma is this. During the cell-division, when the division was almost ended, little cytoplasmic portions become included in the young cell-wall, and it is also very probable that the connective threads, in many instances, are the remaindcr of the "nuclear connective threads," and that the middle-lamellary protoplasm is the remainder of the "cell-plate." All these plasma portions are by the thickened cell-wall much compressed together, and therefore only visible or distinctly visible by the swelling of the cell-wall.

(9) The intercellular plasm can cover itself with a cellmembrane, and in this way we find at the place of the intercellular spaces veritable new cells. About these new cells appears later new secondary or tertiary intercellular spaces.

(Io) The protoplasm of the crystal-bearing cells (crystal glands) and that of the resin-cannel cells is also in communication with the adjacent cells.

The protoplasts of the plants (composed from tissues) form a higher unity, one synplast.

\section{COLLECTING DESMIDS}

$\mathrm{I}$ his recently published "Desmids of the United States" the Rev. T. Wolle gives the following directions for collecting Desmids :-

The outfit need not consist of more than a nest of four or five tin cans (tomato or fruit), one within the other, for convenience of carriage, ten or twelve widemouthed vials, and a small ring-net made of fine muslin at the end of a rod about four feet in length. After selecting what seems to be a good locality, drag the net a few feet among the grasses and mosses, allow the bulk of the water to drain through the muslin, and then empty the residue into one of the cans; repeat this process as often as may be desirable. Ten or fifteen minutes after the cans have been filled most of the surface-water may be poured off, and the remainder transferred to a glass vial, where the solid contents will gradually sink, and the superfluous water can be again poured off, and the vessel

I Gardiner has also obscrved this fact in the plants investigated by him: for this reason we give this in the first place.

J. G. Agardh has also observed endochrome granules in the intercellular spaces of the Florider. See Botanisken Notiser, $188_{4}, \mathrm{p}, 103$. 
filled up with deposits from other vials. In shallow places Sphagnum, Utricularia, Myriophyllum, or other finely cut-leaved water-plants should be lifted in the hand, and the water drained or squeezed from them into a tin can, to be subsequently treated in the same way. A few drops of carbolic acid in each vial, just enough to make its presence perceptible, will preserve the contents for months, and even years, from deterioration; the chlorophyll may fade, but this, in the case of Desmids, is of little importance ; nevertheless, when practicable, always examine the materials when fresh. When dried on paper for the herbarium, the specimen can still, after being moistened with water, be examined under the microscope, but not with the best results, since the drying up is apt to collapse or otherwise distort the cells.

The collector will not know the value of his find until it has been brought, drop by drop, under the microscope ; and out of the entire mass he may discern nothing to reward his labours. This, however, should not discourage him, as one or two failures are to be expected before meeting with an adequate reward. Sketches ought to be made, which should, of course, be very exact ; and for this purpose the microscope should be provided with an eye-piece micrometer. It is so difficult to separate Desmids from their accompanying foreign matters, that it is seldom amateurs can mount them satisfactorily on slides; and this method of preserving specimens cannot therefore be recommended.

\section{RELATIVE FREQUENCY OF STORMS IN THE NORTHERN HEMISPHERE 1}

THE portion of the northern hemisphere selected by the Signal Office of the United States for this discussion is necessarily that part for which the data required are available, and it may be considered as comprising a broad belt of from $30^{\circ}$ to $40^{\circ}$ of latitude in width, extending from the Pacific sea-board of America, through the United States, Canada, the Atlantic, and Europe, with the North of Africa, eastward into Western Siberia. It thus embraces some of the more important regions of the globe, including the great routes of commerce across the Atlantic. The thirteen charts, which show graphically the relative storm frequency for each month and for the year, have been constructed from data referring to 134 months in all, extending from 1863 to 1883 . Of the storms which occurred in this extensive region from January 1876 to August $188 \mathrm{I}$, the history of 2730 is briefly summarised. Of these $4 \mathrm{r} 3$ began and ended in America; 589 began in America and ended in the Atlantic; 190 began in America and crossed the Atlantic ; 326 began and ended in the Atlantic; 655 began in the Atlantic and ended in Europe ; 49x began and ended in Europe; and 66 began in America and crossed the Atlantic and Europe. The important bearing of these facts on the telegraphing from America of forecasts of storms about to strike the coasts of Europe scarcely needs to be referred to further than to remark how essential it is for the usefulness of such a service that it be placed in the hands of some competent and responsible central authority in the United States, as was suggested by us in 1879 (NATURE, vol. xx. p. 359), and which, we believe, has been carried out.

The chart for the year shows that the region where storms occur with greatest frequency is a long belt in America of about 200 miles in width, extending from the head waters of the Red River, about $95^{\circ} \mathrm{W}$. long., eastwards through the Great Lakes to the mouth of the St. Lawrence, about $70^{\circ} \mathrm{W}$. long. Surrounding this is a more

I Charts of Relative Storm Frequency for a Portion of the Northern Hemisphere. Prepared, under the direction of (ieneral W. B. Hazen, Chief Signal Officer of the Army, by John P. Finley, Sergeant, Signal Corps, U.S.A. (Washington: Signal Office, I884.) extensive region where the number of storms, though not so large, is still a good way above the average; and again, surrounding this latter, is a still wider region, stretching from $105^{\circ} \mathrm{W}$. long. eastward through the States and Canada, and through the Atlantic as far as $20^{\circ}$ long. W. This is one of the most important regions of the globe as regards storms or cyclones. The excessive frequency of storms is probably due to a prevalence, during a large portion of the year, of the south-east trades, with a continuation of easterly and southerly winds into and through the Caribbean Sea and Gulf of Mexico, by which, from the superabundant vapour thus poured northward and eastward over the United States by upper and lower currents, frequent storms are originated.

Another region of considerable storm frequency extends from the south of Greenland, through Iceland and Farö, to the north of Sweden. Over this region it may be assumed that a more extended and exhaustive discussion of the storms occurring there than it has been possible to make, will reveal a greater frequency than is indicated on the chart, a supposition rendered highly probable by the frequent and extensive fluctuations of the barometer which occur in Iceland during at least three of the four seasons of the year. Of great interest is the less frequency of storms in the Spanish Peninsula and northeastwards, through Central Europe, as far as Berlin; and the increased frequency to the southward over the northern half of the Mediterranean and the Black Sea, pointing to the important rôle played in the storms of that region by the evaporation from these seas.

This is substantially the distribution of frequency during the colder months of the year, when the larger number of storms occur. In the spring and summer months the distribution is materially altered. Thus, in April the regions of greater frequency extend further to southward in the United States and the Atlantic. It is in Europe, however, where this southing of the tracks of cyclones is most decidedly marked. At this season a broad patch is seen to overspread Ireland and England, and extend thence southward over the north of Spain, and then eastwards over nearly the whole of the south slope of Europe to near the Caspian Sea. As directly connected with the greater prevalence in spring of cyclones in Southern Europe are the east winds, which acquire at this same season their greatest virulence over the north-western part of the Continent. In summer, on the other hand, the coloured patches marking the regions of greater storm-frequency lie further to the northward than at any other season. Thus, in August, immediately to the north of $50^{\circ} \mathrm{N}$. lat., there is an extensive region of greater storm-frequency, of about 900 miles in breadth, extending from about $45^{\circ} \mathrm{W}$. long. to eastward as far as St. Petersburg. In this season the south of Europe is practically rainless, and storms are of extremely rare occurrence.

From the charts, the tracks usually taken by storms in different parts of the wide region under review cannot be ascertained, but can only be guessed at inferentially. It would be a great improvement if, in subsequent issues of the paper, these tracks were entered on the charts. This was done in I882 in the "Physical Atlas of the Atlantic Ocean," prepared under the direction of Dr. Neumayer, of Hamburg. It was there shown from centres of the most frequent occurrence of low barometers, that to the west of the Mississippi is the region where most of the United States storms originate; that many of the Atlantic storms have their origin in the Gulf of St. Lawrence; and that the storms of North-Western Europe chiefly originate in mid-Atlantic and to the south-west of Iceland. The centres of low pressure also pointed to a retardation in the onward course of storms on advancing on large masses of land, as happens when storms approach the south of Greenland, the south of the British Islands, Denmark, and the Lofoten Isles. Of all stormtracks approximately known in the northern hemisphere 